\title{
Histological evaluation of esophageal mucosa in children with acid gastroesophageal reflux
}

\author{
Janusz Semeniuk ${ }^{1}$, Maciej Kaczmarski ${ }^{1}$, Mirosława Uścinowicz ${ }^{1}$, \\ Maria Sobaniec-Lotowska² \\ ${ }^{1}$ III Department of Pediatrics, Medical University of Bialystok, Poland \\ ${ }^{2}$ Department of Medical Pathomorphology, Medical University of Bialystok, Poland
}

\begin{abstract}
AIM: histological evaluation of esophageal mucosa in children, with regard to the duration of primary acid gastroesophageal reflux (GER) and acid GER secondary to cow's milk allergy and/or other food allergy (CMA/FA) (prospective study). MATERIAL AND METHODS: 264 children of both sexes suspected of GER were enrolled in the study. The age of examined children was 1.5-102 months, mean age 20.78 \pm 17.23 months. Pathological acid GER was confirmed with pH-monitoring in 138 children (52.3\%). Taking into consideration complex differential diagnosis, including oral food challenge test with potentially noxious nutrient (open or blind study), children were assigned into study groups 1 and 2 (primary and secondary GER). Group 1: 76 patients $(28.8 \%)$ aged 4-102 months ( $x=25.2 \pm 27.28$ months) with primary GER. Group 2: 62 patients (23.5\%) aged 4-74 months ( $\mathrm{x}=21.53 \pm 17.79$ months) with GER secondary to CMA/FA. Children with GERD underwent preliminary and control (after 1 year and 2 years of GERD diagnosis) endoscopic examination of the upper gastroinestinal tract. RESULTS: Intensity of esophagitis was assessed initially in 25 children from group 1 (32.9\%), in 29 children from group 2 (46.8\%), and in 9 children from group 3 - reference group (28.1\%). Histological evaluation revealed infiltration of inflammatory cells, mainly neutrophils and intraepithelial lymphocytes, and also eosinophils in 10 children (13.2\%) with primary GER. Infiltration of eosinophils and lymphocytes was found in 5 children (8.1\%) with secondary GER. In 8 children $(25.0 \%)$ with food allergy there were only lymphocytes. Infiltration of neutrophils and lymphocytes and basal zone hyperplasia or infiltration of eosinophils and lymphocytes with elongation of lamina propria papillae was found in 10 children $(13.1 \%)$ with primary GER and in 20 children (32.2\%) with secondary GER. Differentiation of particular types of inflammatory cells in mucosal infiltration characterized histological picture in the following way: neutrophils in 21 children (27.6\%) with primary GER, eosinophils in 22 children (35.5\%) with secondary GER, lymphocytes in 15 children (19.7\%) in children with primary GER and in 15 children (24.2\%) with secondary GER. Histological examination of esophageal mucosa after 1 and 2 years of clinical observation and periodical conservative treatment in children with primary and secondary GER revealed significant alleviation of inflammatory abnormalities (with regard to the type of abnormalities and the number of particular types of inflammatory cells). CONCLUSIONS: The value of histological findings obtained in own studies comprises the role of food allergy in pathogenesis of GER and is related to GER's contribution, both direct (primary reflux) and indirect (secondary reflux), to triggering off morphological results and clinical outcomes of esophagitis.
\end{abstract}

Key words: primary and secondary acid gastroesophageal reflux, food allergy, reflux esophagitis, histological evaluation of esophageal mucosa, children

\section{Introduction}

Gastroesophageal reflux disease (GERD) is defined as chronic or recurrent ailments due to pathological return of stomach contents back up into the esophagus

Correspondence: J. Semeniuk, III Department of Pediatrics, Medical University of Białystok, Waszyngtona 17 Str., 15-274 Białystok, Poland; tel./fax.: (+4885) 7423841, e-mail: janexik@poczta.onet.pl and/or damage of esophageal mucousa [1-4]. Diagnostic procedure of key importance for diagnosis of acid gastroesophageal reflux (GER) is still 24-hour $\mathrm{pH}-$ monitoring $[5,6]$.

The diagnosis of esophagitis in patients with acid GER confirmed with $\mathrm{pH}$-monitoring, with aggravated reflux symptoms, should be based on endoscopy. However, different authors (Biller, Shub, Fyderek et al.) suggest that in almost half of such patients (40- 
$50 \%)$ there are no macroscopic inflammatory abnormalities in esophageal mucosa, and inflammation is even less common (30-40\%) in histopathological evaluation [7-12].

The prevalence of reflux esophagitis is $2-5 \%$ in population at developmental age and appears in 4879\% patients with primary GER [4].

Etiopathogenesis and complications of GERD are complex and depend on various agents. This contributes to such a low percentage of diagnosed esophagitis in children and adults [4]. The most important agent in children is primary anatomical immaturity or functional inefficiency of lower esophageal sphincter (LES) and other parts of anti-reflux barrier [4,10-12]. An additional factor in children, regardless of their age, and very often coexisting with GER is food allergy [1,2,13-15].

Food allergy has been diagnosed more often in the past decade and accounts for $2-8 \%$ in children's population and for $1-2 \%$ in adults $[16,17]$. Although it is the most common in infants and the youngest children (03 years of age) and resolves during the first years of life [18], Bishop et al. [19], Tikkonen et al. [20] and our centre [18] report that about $20-50 \%$ of older children have clinical symptoms of persistent food allergy.

Although the etiopathogenetic relationship between acid GER and food allergy during developmental period is still underestimated, it was confirmed in literature and also in own studies [1,2,12,14,15,21-25].

Hill et al. [25] reported that $6 \%$ of the youngest patients with cow's milk allergy had clinical symptoms of GER. Own studies confirmed the coexistence of cow's milk allergy and acid GER in $23.5-44.9 \%$ of patients of various age $[12,22]$. Similar findings were obtained by Italian authors before [21-24].

If the etiopathogenetic contribution of food allergy to secondary reflux is suspected, the cause-and-effect relationship is established on the basis of resolution of reflux symptoms after elimination of noxious nutrients from diet - cow's milk and its derivatives in younger children and other food in older children with reflux.

When similar reflux symptoms appear after oral food challenge test 4-6 weeks later, the interdependence of GER and food allergy is confirmed [2,13,21-24].

Food allergy with typical reflux symptoms provides specific endoscopic and histological pictures of mucosa of upper gastrointestinal tract $[14,16,25,26]$. This is still the object of numerous studies on the youngest children with food hypersensitivity and GER, whereas in older children with persistent allergy $[1,13,14,16,22,25,27,28]$.

The aim of this study was histological evaluation of esophageal mucosa in children with regard to the duration of primary acid gastroesophageal reflux and acid reflux secondary to cow's milk allergy and/or other food allergy (CMA/FA) (prospective study).

\section{Material and methods}

Patients. 264 children suspected of gastroesophageal reflux disease (GERD) of both sexes, 140 boys $(53.0 \%)$ and 124 girls $(47.0 \%)$ underwent 24 -hour esophageal $\mathrm{pH}$-monitoring $[5,6]$. The age of examined children was 1.5-102 months, mean age $20.78 \pm 17.23$ months.

Taking into consideration findings of 24-hour $\mathrm{pH}$-monitoring $[5,6]$ GER was diagnosed in 138 children $(52.3 \%)$.

Taking into account complex differential diagnosis [1,2], especially immunoallergological examinations, including elimination of noxious nutrient, oral food challenge test (biological open or blind study), and the analysis of nutrition in these children $[6,13,21-24]$, reflux was differentiated into primary and secondary (groups 1 and 2).

Group 1: 76 patients (28.8\%), of both sexes, 39 boys (14.8\%), 37 girls (14.0\%), aged 4-102 months (mean age $=25.2 \pm 27.28$ months) with primary GER.

Group 2: 62 patients (23.5\%), of both sexes, 33 boys (12.5\%), 29 girls (11.0\%), aged 4-74 months (mean age $=21.53 \pm 17.79$ months) with GER secondary to CMA/FA.

Group 3 - reference group was made of patients chosen out of 126 patients $(47.7 \%)$ with symptoms suggestive of GERD, with acid GER not confirmed. The group consisted of 32 children $(12.1 \%)$ of both sexes (19 boys $-7.2 \%, 13$ girls $-4.9 \%$ ), aged 7 69 months (mean age $23.7 \pm 12.63$ months) with symptoms suggestive of cow's milk allergy and or other food allergy (CMA/FA).

The remaining 94 patients $(35.6 \%)$, of various age, with symptoms suggestive of GER, who neither have reflux $[5,6]$, nor allergy $[1,2,6,13]$ confirmed to be the cause of ailments, were excluded from the clinical analysis.

Endoscopy of the upper gastrointestinal tract [4,9,29-31]. Endoscopy was performed with XP 20 or N30 endoscope by Olympus under general anesthesia (under supervision of an anesthesiologist). 170 children (64.4\%) of 264 patients suspected of GERD underwent gastroscopy. Significantly aggravated clinical symptoms (typical - of gastrointestinal tract and/or atypical - of respiratory system) were an indication to perform such examination.

Initial macroscopic and histological evaluation of esophageal mucosa (at diagnosis) was performed in 138 children with gastroesophageal reflux disease (GERD): in 76children with primary acid GER (group 1) and in 62 children with secondary GER (group 2).

Endoscopic evaluation of the upper gastrointestinal tract was repeated during clinical observation period and periodical conservative treatment.

Macroscopic and histological findings of esophageal mucosa were evaluated in the following way:

- in 25 children after 1 year and in 9 children of this group after 2 years of clinical observation and periodical anti-reflux treatment (primary reflux)

- in 29 children after 1 year and in 4 children of this group after 2 years of clinical observation and periodical combined treatment: anti-allergic and anti-reflux (secondary reflux).

32 children with CMA/FA (group 3 - reference group) underwent preliminary endoscopy - before treatment. 9 of these children had control endoscopy after 1 year of clinical observation and periodically administered conservative treatment.

The character and morphology of esophageal mucosa was defined on the basis of macroscopic Savara-Miller classification [32], modified by Ollyo et al. [33], in force during the study.

- 0 degree - normal mucosa,

- I degree - mild erythema and fragility of mucosa (dubious inflammation),

- II degree - singular erythematosus erosion and/or erythematoexudative erosion on a single fold,

- III degree - numerous erosions affecting multiple folds of the circumference of esophagus, 
- IV degree - numerous circular erosions affecting total circumference of esophagus,

- V degree - ulcerations, fibrosis, stricture and shortening of esophagus,

- VI degree - Barrett's esophagus.

During gastroscopy, 3 specimens of esophageal mucosa were taken, $2.5 \mathrm{~cm}$ above line $\mathrm{Z}$, where inflammatory abnormalities were present macroscopically, from the top of the fold or the parts with excessive erythema or hyperaemia. Specimens were stained with haematoxylin and eosin and were evaluated in Pathomorphology Department of the Medical University of Bialystok.

The macroscopic findings were verified with histopathological examination of mucosal specimens according to criteria of Black et al. [34] and Ismail-Beigi et al. [35].

The histological criteria of inflammation of esophageal mucosa were as follows (magnification 100-400x):

- 5-10 neutrophils and/or eosinophils in epithelium $\leq 5$ cells for primary reflux and $>7-15$ cells for reflux secondary to CMA/FA and/or

- 10-20 lymphocytes in lamina propria and/or

- basal zone hyperplasia to a length greater than $20 \%$ of epithelial thickness and/or

- elongation of lamina propria papillae to a length greater than $66 \%$ of epithelial thickness

Histological abnormalities confirming inflammation of esophageal mucosa in children who underwent endoscopy were classified in the following way:

- Variant 1 - inflammatory cells exclusively: neutrophils and/or intraepithelial lymphocytes and/or eosinophils.

- Variant 2 (varieties) - inflammatory cells, basal zone hyperplasia or presence of inflammatory cells and elongation of lamina propria papillae.

- Variant 3 - inflammatory cells, basal zone hyperplasia and elongation of lamina propria papillae.

- Variant 4 - histological abnormalities of esophageal mucosa characteristic for Barrett's esophagus.

Endoscopic evaluation of stomach and duodenum was based on Sydney classification [36] - the aim of this evaluation was to confirm or rule out inflammation of stomach (fundus, body, pylorus), duodenum, Helicobacter pylori infection, biliary reflux reaching duodenum to stomach or esophagus. This evaluation was not the subject of further clinical analysis.

Conservative treatment. The diagnosis of acid GER was put forward after 24-hour $\mathrm{pH}$ monitoring and reflux esophagitis was confirmed with endoscopy. Afterwards children underwent complex conservative treatment $[2,14,22,31]$ :

1) children with primray GER (group 1) - standard anti-reflux treatment including: positional treatment (postural) + diet + antacids and protective drugs + parental education, prokinetics, proton pump inhibitors, $\mathrm{H} 2$ receptor inhibitors;

2) children with GER secondary to CMA/FA (group 2) - combined treatment - anti-allergic (eliminatory diet + anti-allergic drugs) and anti-reflux drugs.

The duration of treatment depended on clinical presentation (primary, secondary reflux), the advancement of the disease and effectiveness of treatment.

Control endoscopy and control esophageal $\mathrm{pH}$-monitoring and, in the case of secondary reflux oral food challenge test were performed after 1 and 2 years since preliminary study (at diagnosis).

Ethical issues. The study was approved by local Bioethical Committee of the Medical University of Bialystok and informed written parental consent was obtained from parents of examined children.

Statistical analysis. The statistical analysis of the results comprised arithmetical mean, standard deviation, minimal and maxi- mal values and median - for measurable features, and quantitative percentage distribution for qualitative features. To compare the groups, features compatible with normal distribution (assessed with Kolomogorov compatibility test) were assessed together with the post hoc Bonferroni one-way analysis of variance. Features noncompatible with the distribution underwent Kruskal-Wallis test and Mann-Whitney test was applied if the differences were statistically significant. Statistical significance was $p<0.05$. Calculations were performed with the help of statistical package SPSS'12.0 PL.

\section{Results}

138 children, with acid GER confirmed with 24- hour $\mathrm{pH}$ monitoring (group 1 and 2), underwent gastroscopy in order to confirm or rule out esophagitis. 54 of these 138 children (39.1\%) had inflammation of esophageal mucosa of various intensity found in endoscopy (in both macroscopic and histological assessment). Out of 32 children with CMA/FA (group 3 - reference group) with acid GER not confirmed with $\mathrm{pH}$ monitoring, 9 (28.1\%) had inflammation of esophageal mucosa of 1st degree in endoscopy.

\section{Histological evaluation of esophageal mucosa (Table 1)}

The intensity of inflammation of esophageal mucosa was initially evaluated in 25 children $(32.9 \%)$ from group 1 (Figure 1, 2), in 29 children $(46.8 \%)$ from group 2 (Figure 3,4 ) and in 9 patients $(28.1 \%$ ) from group 3.

Variant 1. Inflammatory cells infiltration, mainly neutrophils and intraepithelial lymphocytes, sometimes eosinophils in 10 children $(13.2 \%)$ with primary reflux. Infiltration of eosinophils and lymphocytes in 5 patients $(8.1 \%)$ with secondary reflux. In 8 children $(25.0 \%)$ with food allergy and with inflammation of esophageal mucosa of 1 st degree only intraepithelial lymphocytes.

Variant 2. Infiltration of neutrophils and intraepithelial lymphocytes with basal zone hyperplasia or infiltration of eosinophils and lymphocytes with elongation of lamina propria papillae in 10 children $(13.1 \%)$ with primary reflux and in 20 children $(32.2 \%)$ with secondary reflux.

Variant 3. Specified types of histological abnormalities were present in 5 children $(6.6 \%)$ with primary reflux and in 4 children $(6.5 \%)$ with secondary reflux.

Variant 4. Only in one 6-year-old child $(1.3 \%)$ with primary reflux (group 1) there was columnar epithelium (intestinal) in mucosa typical for Barrett's esophagus with all histological abnormalities evaluated.

\section{Histological evaluation after 1 year of conservative treatment (Table 1)}

Histological abnormalities of esophageal mucosa were present in 27 children (15.9\%) with reflux esophagitis: 

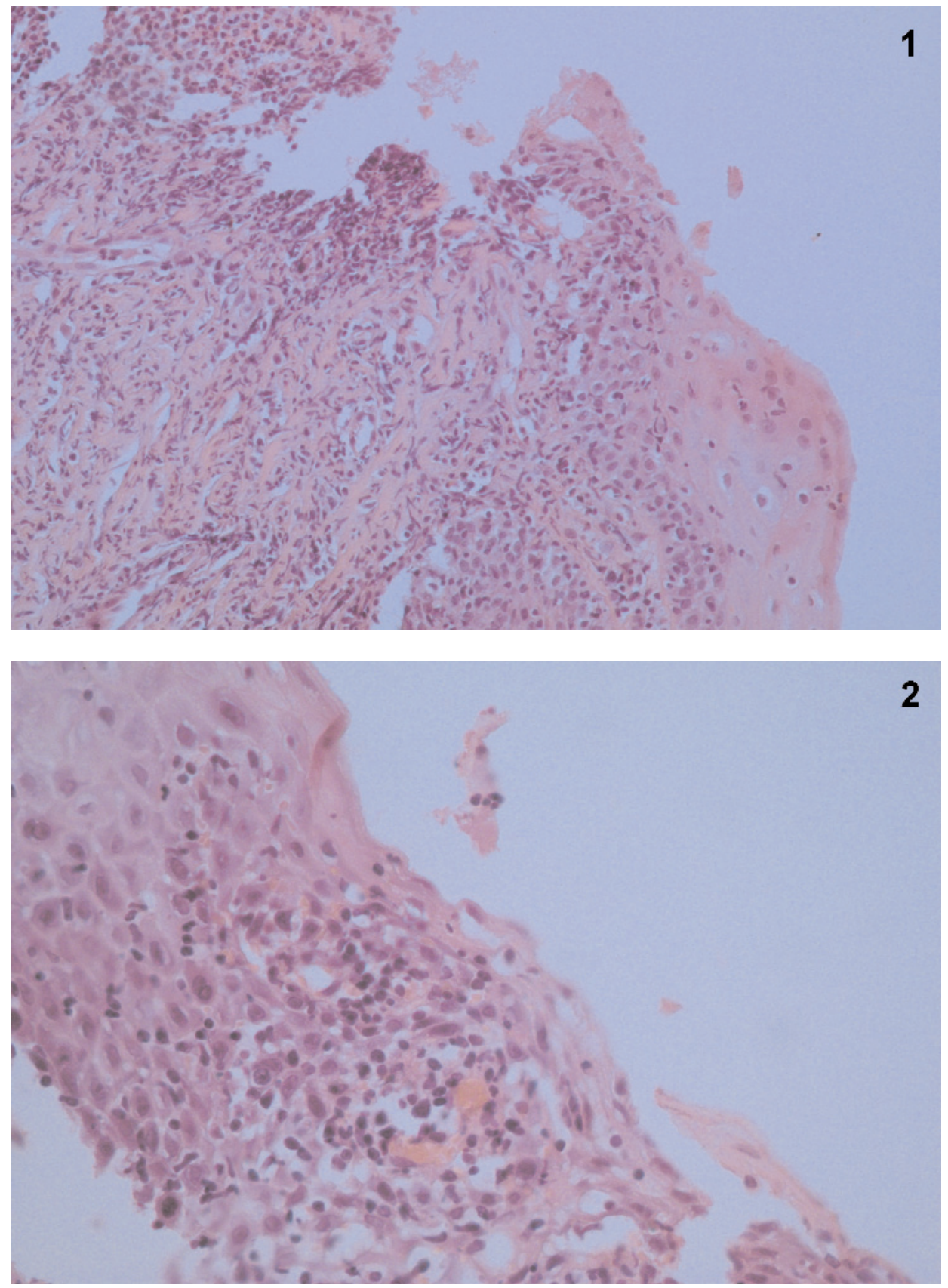

Fig. 1. Esophageal mucosa with ulceration. Numerous neutrophils in necrotic mass, connective tissue stroma, and in paraepidermoidal epithelium $(\mathrm{H}+\mathrm{E}$, original magnification $\times 200$ ).
Fig. 2. Paraepidermoidal epithelium of esophagus with massive infiltration with the predominance of neutrophils $(\mathrm{H}+\mathrm{E}$, original magnification $\times 400$ ).
13 children in group 1, 12 children in group 2 and 2 children in group 3.

Neutrophils and lymphocytes were only found in 2 patients $(2.6 \%)$ with primary reflux, whereas eosinophils and lymphocytes in 5 children $(8.1 \%)$ with secondary reflux (variant 1).

Lymphocytes and neutrophils (occasionally eosinophils) with basal zone hyperplasia or eosinophils and lymphocytes with elongation of lamina propria papillae were found in 5 children $(6.6 \%)$ with primary reflux and in 3 children (4.8\%) with secondary reflux (variant 2 or 3 ).

These types of histological changes were present in 4 children $(5.3 \%)$ with primary reflux. Among these patients there were: 1 child (1.3\%) with Barrett esophagus and 1 child (1.6\%) with reflux secondary to allergy.

\section{Histological evaluation after 2 years of conservative treatment (Table 1)}

After 2 years of conservative treatment histological abnormalities in esophageal mucosa were present in 6 children $(3.5 \%)$ of 13 patients from the examined groups i.a. 9 patients from group 1 and 4 patients from group 2.

Eosinophils and/or lymphocytes were found in 3 children $(4.8 \%)$ with reflux secondary to allergy (group 2). 

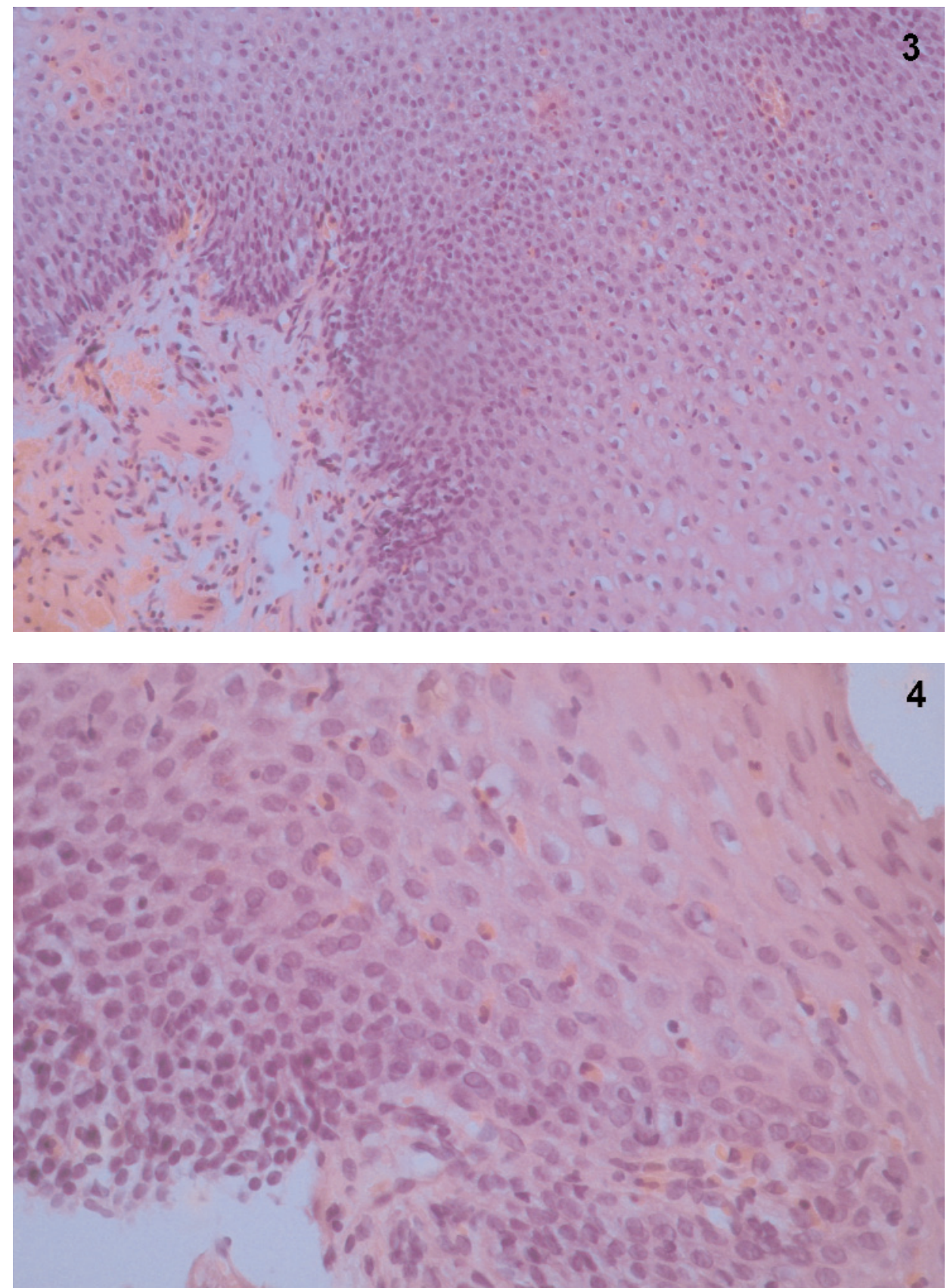

Fig. 3,4. Paraepidermoidal epithelium of esophagus with numerous eosinophils $(\mathrm{H}+\mathrm{E}$, fig. 3 - original magnification $\times 100$, fig. 4 - original magnification $\times 400$ )
Intraepithelial lymphocytes and basal zone hyperplasia coexisting with metaplastic columnar epithelium, typical for Barrett's esophagus were present in only 1 child $(1.3 \%)$ with primary reflux (group 1) (still the same patient).

The differentiation of particular types of inflammatory cells in infiltration, which characterize histological abnormalities of esophagitis diagnosed initially in children in groups 1,2 and 3 is classified in the following way (Table 2):

- neutrophils were present in 21 children (27.6\%) with primary reflux and in 2 children (3.2\%) with secondary reflux
- eosinophils were present in 22 children $(35.5 \%)$ with secondary reflux, in 4 children $(5.3 \%)$ with primary reflux and in 4 children $(12.5 \%)$ with food allergy;

- intraepithelial lymphocytes were present with similar incidence in groups 1 and 2: in 15 children $(19.7 \%)$ with primary reflux and in 15 children $(24.2 \%)$ with secondary reflux, respectively, and in 8 children $(25.0 \%)$ with food allergy (group 3).

After 1-year-treatment of gastroesophageal reflux, the characteristic of cells in esophageal mucosa in children in group 1 and 2 presented as fol- 
Table 1. Histological characteristics of inflammation of esophageal mucosa in 138 children with primary and secondary acid GER and in 32 children with CMA/FA (prospective study).

\begin{tabular}{|c|c|c|c|c|c|c|c|c|c|c|c|c|c|}
\hline \multirow[b]{3}{*}{$\begin{array}{l}\text { Groups of } \\
\text { examined } \\
\text { children }\end{array}$} & \multicolumn{13}{|c|}{ Histological evaluation of inflammation of esophageal mucosa } \\
\hline & \multicolumn{5}{|c|}{$\begin{array}{l}\text { Before treatment }(0) \\
\mathrm{N}(\%)\end{array}$} & \multicolumn{5}{|c|}{$\begin{array}{c}\text { After 1-year treatment } \\
\mathrm{N}(\%)\end{array}$} & \multicolumn{3}{|c|}{$\begin{array}{c}\text { After 2-year treatment } \\
\text { N }(\%)\end{array}$} \\
\hline & 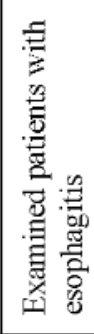 & 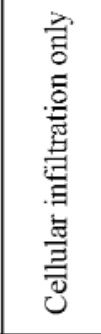 & 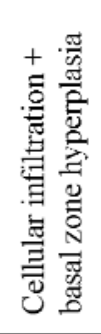 & 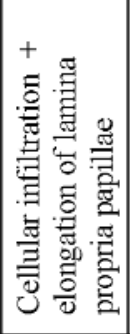 & 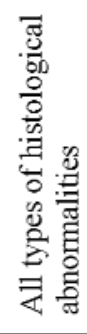 & 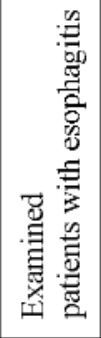 & 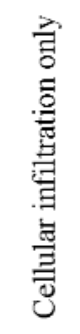 & 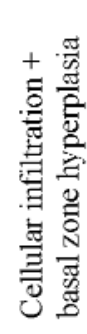 & 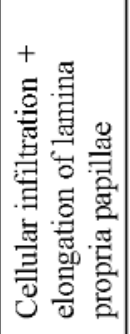 & 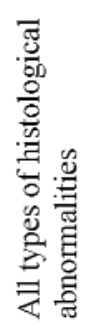 & 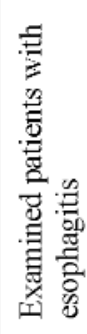 & 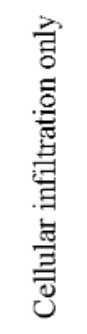 & 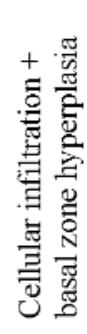 \\
\hline $\begin{array}{l}\text { Group l } \\
\text { primaty GER } \\
\mathrm{N}=76\end{array}$ & $\begin{array}{c}25 \\
(32.9)\end{array}$ & $\begin{array}{c}10 \\
(13.2)\end{array}$ & $\begin{array}{c}7 \\
(9.2)\end{array}$ & $\begin{array}{c}3 \\
(3.9)\end{array}$ & $\begin{array}{l}5^{*} \\
(6.6)\end{array}$ & $\begin{array}{c}13 \\
(17.1)\end{array}$ & $\begin{array}{c}2 \\
(2.6)\end{array}$ & $\begin{array}{c}4 \\
(5.3)\end{array}$ & $\begin{array}{c}1 \\
(1.3)\end{array}$ & $\begin{array}{c}4^{*} \\
(5.3)\end{array}$ & $\begin{array}{c}3 \\
(3.9)\end{array}$ & - & $\begin{array}{c}1^{*} \\
(1.3)\end{array}$ \\
\hline $\begin{array}{l}\text { Group 2 GER } \\
\text { secondary to } \\
\text { CMA/FA } \\
N=62\end{array}$ & $\begin{array}{c}29 \\
(46.8)\end{array}$ & $\begin{array}{c}5 \\
(8.1)\end{array}$ & $\begin{array}{c}11 \\
(17.7)\end{array}$ & $\begin{array}{c}9 \\
(14.5)\end{array}$ & $\begin{array}{c}4 \\
(6.5)\end{array}$ & $\begin{array}{c}12 \\
(19.4)\end{array}$ & $\begin{array}{c}5 \\
(8.1)\end{array}$ & $\begin{array}{c}1 \\
(1.6)\end{array}$ & $\begin{array}{c}2 \\
(3.2)\end{array}$ & $\begin{array}{c}1 \\
(1.6)\end{array}$ & $\begin{array}{c}3 \\
(4.8)\end{array}$ & $\begin{array}{c}3 \\
(4.8)\end{array}$ & - \\
\hline $\begin{array}{l}\text { TOTAL N=138 } \\
(100.0 \%)\end{array}$ & $\begin{array}{c}54 \\
(39.1)\end{array}$ & $\begin{array}{c}15 \\
(10.9)\end{array}$ & $\begin{array}{c}18 \\
(13.0)\end{array}$ & $\begin{array}{c}12 \\
(8.7)\end{array}$ & $\begin{array}{c}9 \\
(6.5)\end{array}$ & $\begin{array}{c}25 \\
(18.1) \\
\end{array}$ & $\begin{array}{c}7 \\
(5.1)\end{array}$ & $\begin{array}{c}5 \\
(3.6)\end{array}$ & $\begin{array}{c}3 \\
(2.2)\end{array}$ & $\begin{array}{c}5 \\
(3.6)\end{array}$ & $\begin{array}{c}6 \\
(4.3)\end{array}$ & $\begin{array}{c}3 \\
(2.2)\end{array}$ & $\begin{array}{c}1 \\
(0.7)\end{array}$ \\
\hline $\begin{array}{l}\text { Group 3- } \\
\text { reference group } \\
\text { CMA/FA } \\
\mathrm{N}=32\end{array}$ & $\begin{array}{c}9 \\
(28.1)\end{array}$ & $\begin{array}{c}8 \\
(25.0)\end{array}$ & - & - & - & $\begin{array}{c}2 \\
(3.2)\end{array}$ & - & - & - & - & - & - & - \\
\hline $\begin{array}{l}\text { ALTOGETHER } \\
\mathrm{N}=170 \\
(100.0 \%)\end{array}$ & $\begin{array}{c}63 \\
(37.1)\end{array}$ & $\begin{array}{c}15 \\
(8.8)\end{array}$ & $\begin{array}{c}18 \\
(10.6)\end{array}$ & $\begin{array}{c}12 \\
(7.1)\end{array}$ & $\begin{array}{c}9 \\
(5.3)\end{array}$ & $\begin{array}{c}27 \\
(15.9)\end{array}$ & $\begin{array}{c}7 \\
(4.1)\end{array}$ & $\begin{array}{c}5 \\
(2.9)\end{array}$ & $\begin{array}{c}3 \\
(1.8)\end{array}$ & $\begin{array}{c}5 \\
(2.9)\end{array}$ & $\begin{array}{c}6 \\
(3.5)\end{array}$ & $\begin{array}{c}3 \\
(1.8)\end{array}$ & $\begin{array}{c}1 \\
(0.6)\end{array}$ \\
\hline
\end{tabular}

*1 child $(1.3 \%)$ with concomitant histological changes typical for Barrett's esophagus

lows (Table 2): neutrophils were found in 6 children $(7.9 \%)$ with primary reflux (group 1); intraepithelial lymphocytes were present with similar incidence in group 1 and 2: 11 children (14.5\%) with primary reflux and 7 children (11.3\%) with secondary reflux, respectively; eosinophils were present only in 2 children $(2.6 \%)$ with primary reflux and in 8 children (12.9) with secondary reflux (4 times more often than in group 1).

Only in 1 child $(1.3 \%)$ with primary GER and Barrett's esophagus after 2 years of treatment there were single neutrophils, intraepithelial lymphocytes and eosinophils, and in 2 out of 3 children (3.2\%) with secondary GER there were eosinophils and in 1 of these patients $(1.6 \%)$ single intraepithelial lymphocytes.

\section{Discussion}

Hydrochloric acid secretion and acidity of reflux content are of key importance in ethiopathogenesis of GER and its complications such as esophagitis $[3,4,7-$ 12,29,30,37-39].
Therefore, evaluation of reflux focuses on effects that hydrochloric acid has on esophageal mucosa and its damage.

In children with GER and its adverse outcomes (morphological and clinical), regardless of their age, the etiopathogenetic influence of food hypersensitivity has been emphasized lately since it has negative influence on gastrointestinal tract motility $[1,2,12,14,15,21-25]$.

Ravelli et al. [40] reported that oral food challenge test with cow's milk in infants allergic to cow's milk led to bradygastry and delayed gastric emptying.

Delayed emptying results in stretching stomach walls and activates afferent fibers of vagus nerve resulting in excessive relaxation of LES [40].

In Poland, Kaczmarski et al. [12,15,22] reported similar observations suggesting food hypersensitivity to be the triggering factor of GER $[12,15,22]$. They confirmed harmful contribution of some food (cow's milk proteins, soy milk, citrus fruit and other products) and suggested pathogenetic outcomes of this hypersensitivity in esophageal mucosa and stomach such as hyperaemia, oedema, erosions, and clinical symptoms such as abdominal pains. 
Table 2. Characteristic of histological abnormalities of inflammation of esophageal mucosa including particular inflammatory cell types in 138 children with primary and secondary acid GER, and in 32 children with CMA/FA (prospective study).

\begin{tabular}{|c|c|c|c|c|c|c|c|c|c|c|c|c|}
\hline \multirow{3}{*}{$\begin{array}{l}\text { Groups of examined } \\
\text { children }\end{array}$} & \multicolumn{12}{|c|}{$\begin{array}{c}\text { Types of inflammatory cells characteristic for histological abnormalities in inflammation of esophageal } \\
\text { mucosa }\end{array}$} \\
\hline & \multicolumn{4}{|c|}{$\begin{array}{l}\text { Before treatment }(0) \\
\text { N }(\%)\end{array}$} & \multicolumn{4}{|c|}{$\begin{array}{c}\text { After 1-year treatment } \\
\mathrm{N}(\%)\end{array}$} & \multicolumn{4}{|c|}{$\begin{array}{c}\text { After 2-year treatment } \\
\mathrm{N}(\%)\end{array}$} \\
\hline & 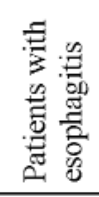 & $\begin{array}{l}\frac{\infty}{3} \\
\frac{2}{0} \\
\frac{G}{3} \\
\text { z }\end{array}$ & 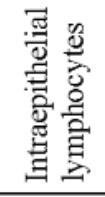 & 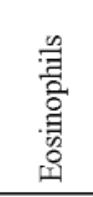 & 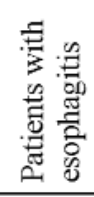 & 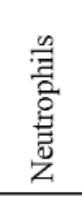 & 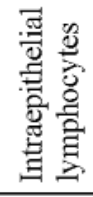 & 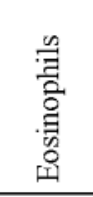 & 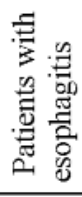 & 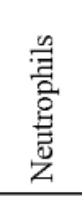 & 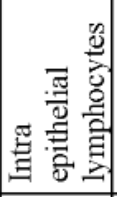 & 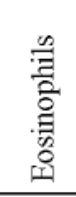 \\
\hline $\begin{array}{l}\text { Group } 1 \text { primary GER } \\
\mathrm{N}=76\end{array}$ & $\begin{array}{c}25 \\
(32.9)\end{array}$ & $\begin{array}{c}21 \\
(27.6)\end{array}$ & $\begin{array}{c}15 \\
(19.7)\end{array}$ & $\begin{array}{c}4 \\
(5.3)\end{array}$ & $\begin{array}{c}13 \\
(17.1)\end{array}$ & $\begin{array}{c}6 \\
(7.9)\end{array}$ & $\begin{array}{c}11 \\
(14.5)\end{array}$ & $\begin{array}{c}2 \\
(2.6)\end{array}$ & $\begin{array}{c}3 \\
(3.9)\end{array}$ & $\begin{array}{c}1^{*} \\
(1.3)\end{array}$ & $\begin{array}{c}1^{*} \\
(1.3)\end{array}$ & - \\
\hline $\begin{array}{l}\text { Group } 2 \text { GER } \\
\text { secondary to CMA/FA } \\
\mathrm{N}=62\end{array}$ & $\begin{array}{c}29 \\
(46.8)\end{array}$ & $\begin{array}{c}2 \\
(3.2)\end{array}$ & $\begin{array}{c}15 \\
(24.2)\end{array}$ & $\begin{array}{c}22 \\
(35.5)\end{array}$ & $\begin{array}{c}12 \\
(19.4)\end{array}$ & - & $\begin{array}{c}7 \\
(11.3)\end{array}$ & $\begin{array}{c}8 \\
(12.9)\end{array}$ & $\begin{array}{c}3 \\
(4.8)\end{array}$ & - & $\begin{array}{c}1 \\
(1.6)\end{array}$ & $\begin{array}{c}3 \\
(4.8)\end{array}$ \\
\hline $\begin{array}{l}\text { TOTAL N=138 } \\
(100.0 \%)\end{array}$ & $\begin{array}{c}54 \\
(39.1)\end{array}$ & $\begin{array}{c}23 \\
(16.6)\end{array}$ & $\begin{array}{c}30 \\
(21.7)\end{array}$ & $\begin{array}{c}26 \\
(18.8)\end{array}$ & $\begin{array}{c}25 \\
(18.1)\end{array}$ & $\begin{array}{c}6 \\
(4.3)\end{array}$ & $\begin{array}{c}18 \\
(13.0)\end{array}$ & $\begin{array}{c}10 \\
(7.2)\end{array}$ & $\begin{array}{c}6 \\
(4.3)\end{array}$ & $\begin{array}{c}1 \\
(0.7)\end{array}$ & $\begin{array}{c}2 \\
(1.4)\end{array}$ & $\begin{array}{c}3 \\
(2.2)\end{array}$ \\
\hline $\begin{array}{l}\text { Group } 3 \text { - reference } \\
\text { group CMA/l'A } \\
\mathrm{N}=32\end{array}$ & $\begin{array}{c}9 \\
(28.1)\end{array}$ & - & $\begin{array}{c}8 \\
(25.0)\end{array}$ & $\begin{array}{c}4 \\
(12.5)\end{array}$ & $\begin{array}{c}2 \\
(3.2)\end{array}$ & - & - & - & - & - & - & - \\
\hline
\end{tabular}

* in 1 child $(1,3 \%)$ with Barrett's esophagus

Relaxation of LES and low esophageal $\mathrm{pH}$ due to allergen administration were also the cause of atypical symptoms of GER such as obstructive bronchopneumonia in these children [15,22].

In own studies, similarly to reports of Staiano et al.[24], in children with intensified clinical symptoms of reflux, esophagitis was diagnosed on the basis of intraesophageal $\mathrm{pH}$-monitoring, which confirmed the acidity of reflux and the outcomes of esophageal mucosa damage in endoscopy and histopathological evaluation.

Food allergy was considered the cause of acid GER (secondary reflux) on the basis of elimination of cow's milk and/or other noxious food from children's diet if the reflux symptoms resolved and reappeared after oral food challenge test 4-6 weeks later (biological food trial) $[2,13,14,21-24]$.

GERD was diagnosed in 138 children after intraesophageal $\mathrm{pH}$-monitoring and oral food challenge test. In 76 patients $(55.1 \%)$ it was primary reflux and in 72 patients $(44.9 \%)$ reflux secondary to $\mathrm{CMA} / \mathrm{FA}$. Esophagitis was diagnosed in 54 children (39.1\%) in initial endoscopy - 25 children with primary reflux (32.9\%) and 29 children with secondary reflux (46.8\%).

Patophysiological background of mucosal inflammation in GERD comprises in the first place anatomical immaturity and/or functional impairment of particular parts of antireflux barrier, especially lower esophageal sphincter (LES), irrespective of the cause of reflux (primary or secondary).
Spontaneous transient relaxation of LES, considered the main pathogenetic mechanism of reflux, does not play the key role in patients with secondary reflux associated with food allergy $[4,5,9,14,15,21-24]$.

Presumably due to chronic allergization of upper gastrointestinal tract with noxious nutrient, its motility is disturbed on the level of gastroesophageal junction resulting in long-lasting inefficiency of $\operatorname{LES}[14,15$, $21,25,41]$.

Taking into consideration the influence of various stimuli such as nutritive, humoral, nervous stimuli on the control of LES, we registered constantly lower values of resting LES pressure in children with secondary reflux than in children with primary reflux. However the differences in LES pressure between the groups were not statistically significant $(p=0.088)$ (the results are prepared to be published).

Since there are neither endoscopic nor histological proves for mucosal inflammation in $61 \%$ of children with active GERD, it is possible that other anti-reflux mechanisms such as esophageal corpus motility, epithelium's resistance to chronic chemical damage, control of hydrochloric acid secretion in stomach, gastric emptying or esophageal emptying are more efficient.

The type of macroscopic abnormalities defining morphological effects of reflux esophagitis was different in both groups in preliminary study. The prevalence of esophagitis of high intensity (3rd or 4th degree) was comparable in both groups, and esophagi- 
tis of lower intensity (2nd degree) was 2 times more common in the group with secondary reflux.

After 1 year of conservative treatment (anti-reflux, anti-allergic) chronic reflux esophagitis was still observed in control endoscopy in 25 out of 63 examined patients (18.1\%), however it was less intense. The prevalence of esophagitis of $3 \mathrm{rd}$ or 2 nd degree was comparable in both groups, but esophagitis of $1 \mathrm{st}$ degree was over 2 times higher in group with secondary reflux than in group with primary reflux.

Preliminary histological evaluation of mucosa showed mainly quantitative and qualitative differentiation of inflammatory cells in all examined children from group 1 and 2.

In children with primary reflux there was mainly neutrophilic infiltration in $84 \%$ with the number of cells ranging from 5 to 13 (mean 6.5 in high magnification).

Histological findings of inflammatory cells in mucosal specimens in this kind of patients were reported by Iwańczak, Fyderek, Vieira, Orenstein and Cherian $[4,9,30,42,43]$.

In $60 \%$ of patients with primary reflux there was higher number of intraepithelial lymphocytes, and only in $16 \%$ of children eosinophils were present in infiltration. The number of cells varied from 1 to 5 (mean 2.3) in high magnification. In 29 children with secondary reflux $(46.8 \%)$ eosinophils were predominant $(76 \%)$, the number of eosinophils varied from 7 to 15 (mean 8.7) in high magnification. In 52\% of examined patients there were intraepithelial lymphocytes, and solitary neutrophils were present in only $7 \%$ of children.

The results of histological evaluation of esophageal mucosa obtained in own studies are similar to results presented by Winter et al. [44].

They reported the presence of a few intraepithelial eosinophils in children with confirmed acid GER. Since then, the presence of eosinophils has been considered to be the diagnostic indicator of GER, however without differentiation into primary or secondary [44].

Variable number of intraepithelial eosinophils in esophagus of young people and children in microscopic assessment has been used to differentiate eosinophilic and reflux esophagitis by some authors Spergel, Attwood, Justinish, Walsh et al. [41,45-47].

They decided that over 20 eosinophils in high power field (hpf) in esophageal mucosa is the morphological indicator of eosinophilic inflammation of esophagus only or the total gastrointestinal tract [41,45-47].

In De Angelis, Spergel, Orenstein, Rothenberga et al. $[31,41,42,48]$, and own studies quantitative assessment of inflammatory cells in biopsy specimens of mucosa especially of distal esophagus could be the diagnostic criterion and help to differentiate reflux into primary and secondary to $\mathrm{CMA} / \mathrm{FA}$ or eosinophilic mucosal inflammation.

The presence of 1-5 eosinophils in mucosa could suggest esophagitis due to primary reflux. Therefore the presence of higher number of eosinophils (>7$15 / \mathrm{hpf}$ ) could suggest inflammation due to reflux secondary to food allergy. The high number of eosinophils is more likely to suggest primary eosinophilic inflammation of mucosa of stomach and/or intestines. Moreover, own studies show that expanded diagnostics towards food allergy is justified especially in those patients who have allergy in family history and/or positive results of allergological tests.

Own studies comprising the diagnosis of GER on the basis of 24-hour esophageal $\mathrm{pH}$ - monitoring and/or endoscopy, histological evaluation of biopsy specimens (mainly with eosinophilic infiltration up to 15 cells/hpf) and positive result of oral food challenge test suggest and confirm the allergy to be the triggering factor of GER. Histopathological evaluation of esophageal mucosa in both groups after 1 year of conservative treatment (anti-reflux and/or anti-allergic) showed that inflammatory changes were also less intense. In group with primary reflux only in 11 children $(13.5 \%)$ lymphocytes were predominant in $100 \%$, neutrophils were present in half of the children from this group. In group with secondary reflux in 9 children (14.5\%) eosinophils in histological evaluation were present in $89 \%$ and/or lymphocytes in $78 \%$.

Comparing the results of preliminary study with control study after 1 year of clinical observation and treatment, neutrophils in histological picture of esophageal mucosa were observed significantly more often in group with primary reflux $(\mathrm{p}<0.0001)$, eosinophils were predominant in group with reflux secondary to food allergy $(p<0.0002)$. At the same time intraepithelial lymphocytes were observed with similar frequency in both groups ( $\mathrm{p}=\mathrm{ns}$ ).

After 2 years of conservative treatment only 13 children with persistent reflux esophagitis underwent another endoscopy: 9 children from group 1 and 4 children from group 2.

In group with primary reflux esophagitis of 2 nd degree was observed macroscopically in 3 children, and in 18 -year-old child with Barrett's esophagus single neutrophils and lymphocytes were observed.

In group with secondary reflux esophagitis of 1st degree was observed macroscopically in 3 children. Histological evaluation showed some eosinophils in $100 \%$ of examined children and intraepithelial lymphocytes in $33 \%$ of patients.

In both groups in endoscopy (macroscopic picture) inflammatory changes were of little or mild intensity, especially erythema or fragility of mucosa and did not stay in relationship with changes present in histologi- 
cal assessment (microscopic picture). These children were dismissed from regular endoscopic control. Only one child with Barrett's esophagus was obliged to undergo control endoscopy (group 1).

It should be emphasized that there was a positive correlation of the results of endocopic and histological evaluation in both groups at diagnosis of esophagitisin group $1(\mathrm{r}=0.5581 ; \mathrm{p}=0.0034)$, in group 2 $(\mathrm{r}=0.6037 ; \mathrm{p}=0.0022)$. There was no such correlation in control studies. Similar results in endoscopic and histological evaluation were reported by CzerwionkaSzaflarska et al. [49].

In conclusion, on the basis of consecutive endoscopic and histological assessments performed periodically in our department in children with primary and secondary reflux (prospective study) we observed gradual resolution of the morphological outcomes of reflux esophagitis.

After 1 year of clinical observation and periodical conservative treatment in children with esophagitis, significant improvement was obtained in $48 \%$ of children from group with primary reflux and in $58.6 \%$ of children from group with secondary reflux. After 2 years, the improvement was observed in $88 \%$ and $89.7 \%$ in group with primary reflux and in group with secondary reflux, respectively.

Other authors did not observe the progression of GERD diagnosed at developmental age. Ollyo et al. [49] reported further progression of the disease in $23 \%$ of patients with erosive esophagitis, improvement in $31 \%$ of children and spontaneous resolution in $46 \%$ of patients. Tolia et al. [50] in the study on children with erosive esophagitis showed improvement in $78 \%$ of patients after 8-week anti-reflux treatment, and in $100 \%$ of patients after 12 weeks. Wakil et al. [51] reported resolution of reflux esophagitis in $54,2 \%$ $87.9 \%$ of patients after 6 -month conservative treatment.

The duration of inflammation of esophageal mucosa and its morphological outcomes evaluated after 2 years of clinical observation and periodically administered treatment in selected patients was comparable between the groups. However, the duration of clinical outcomes of esophagitis in these patients was differentiated between the groups and depended on the type of administered treatment and its effectiveness.

Selection of proper and effective treatment in both groups resulted from the diagnosis or disqualification of active allergy in these patients. Allergy, if not diagnosed on time, resulted in preservation of morphological changes in mucosa and had influence on chronic character, persistence and recurrence of reflux symptoms related to the advanced stage of inflammation and significantly diminished the effects of improperly chosen anti-reflux treatment, which did not considered allergy.
In patients with GER who had food allergy (group 2) it was advisable to administer anti-allergic treatment together with anti-reflux treatment. Positive effect achieved due to treatment enriched with eliminatory diet and anti-allergic drugs suggests allergy to be the cause of secondary reflux with its negative complications $[2,12,14,22,31]$.

The value of histological results obtained in own studies comprises the proven role of food allergy in pathogenesis of GER and direct influence of GER (primary reflux) or indirect influence of reflux (secondary reflux) on morphological and clinical results of esophagitis.

\section{References}

[ 1] Semeniuk J, Kaczmarski M. Refluks żołądkowo-przełykowy u dzieci i młodzieży. Aspekty kliniczne ze szczególnym uwzględnieniem nadwrażliwości pokarmowej. Adv Med Sci. 2006;51:327-335.

[2] Semeniuk J, Kaczmarski M. Refluks żołądkowo-przełykowy u dzieci i młodzieży. Aspekty diagnostyczne ze szczególnym uwzględnieniem nadwrażliwości pokarmowej. Adv Med Sci. 2006;51:321-326

[3] Nowak A, Marek T. Choroba refluksowa przełyku. Med Sci Rev. 2002;1:24-32.

[4] Iwańczak B. Korelacje kliniczno-morfologiczne choroby refluksowej u dzieci. Rozprawa habilitacyjna. Akademia Medyczna Wrocław; 1998.

[5] Vandenplas Y. Oesophageal pH monitory for gastrooesophageal reflux in infants and children. John Wiley and sons, 1992; Ch.6, pp. 103-179.

[6] Semeniuk J, Kaczmarski M. 24-hour esophageal pH-monitoring in children suspected of gastroesophageal reflux disease. Analysis of intraesophageal $\mathrm{pH}$ monitoring values recorded in distal and proximal channel at diagnosis. World $J$ Gastroenterol. 2007; 13:5108-5115.

[ 7] Biller JA, Winter HS, Grand RJ, Alfred EN. Are endoscopic changes predictive of histologic esophagitis in children? J Pediatr. 1983;103:215-218.

[ 8] Shub MD, Ulshen MH, Hargrove CB, Siegal GP, Groben PA. Esophagitis: a frequent consequence of gastroesophageal reflux in infancy. J Pediatr. 1985;107:881-884.

[9] Fyderek K. Choroba refluksowa i inne zaburzenia motoryki przełyku u dzieci. Wydawnictwo- Medycyna praktyczna Kraków, 1998;1:11-53.

[10] Grupa Robocza Polskiego Towarzystwa Gastroenterologii. Wytyczne Polskiego Towarzystwa Gastroenterologii: choroba refluksowa przełyku. Gastroenterol Pol. 2005;12:313319.

[11] Ksiądzyna D. Postępy w gastroenterologii w 2002 roku choroby przełyku. Gastroenterol Pol. 2003;10:135-147.

[12] Kaczmarski M, Semeniuk J, Sidor K, Wasilewska J, Nowowiejska B. Zarzucanie treści żołądkowej i/lub dwunastniczej do przełyku u pacjentów w wieku rozwojowym a skuteczność stosowanej terapii. Przegl Gastroenterol. 2007;2: 5-12.

[13] Kaczmarski M. Stanowisko Polskiej Grupy Ekspertów d/s Alergii i Nietolerancji Pokarmowej. Alegia i nietolerancja pokarmowa. Polskie Towarzystwo Alergologiczne, Sympozjum 1, Medyczne Czasopismo Zjazdowe, UNIMED. 1997;1:21-31,39-67.

[14] Salvatore S, Vandenplas Y. Gastroesophageal reflux and cow milk allergy: is there a link? Pediatrics. 2002;110:972-984. 
[15] Semeniuk J, Tryniszewska E, Wasilewska J, Kaczmarski M. Alergia pokarmowa-czynnik przyczynowy wstecznego odpływu żołądkowo-przełykowego u dzieci. Terapia. 1998; 6:16-19.

[16] Jarocka-Cyrta E, Pawlak J, Topczewska M, Kaczmarski M. Obraz morfologiczny błony śluzowej dwunastnicy u starszych dzieci z wywiadem obciążonym alergią na białka mleka krowiego w okresie niemowlęcym. Badania immunohistochemiczne i morfometryczne. Ped Wsp, Gastroenterol, Hepatol i Żywienie Dziecka. 2007;9(2):98-101.

[17] Vandenplas Y, Breton M, Dupent C, et al. Guidelines for the diagnosis and management of cow's milk protein allergy in infants. Arch Dis Child. 2007;92:902-908.

[18] Jarocka-Cyrta E, Baniukiewicz A, Wasilewska J, Pawlak J, Kaczmarski M. Ogniskowy zanik kosmków błony śluzowej dwunastnicy u starszych dzieci $\mathrm{z}$ alergia na białka mleka krowiego rozpoznaną $\mathrm{w}$ wieku niemowlęcym. Badania $\mathrm{z}$ zastosowaniem endoskopii z powiększeniem i chromoendoskopii. Med Wieku Rozwoj. 2007;2:123-127.

[19] Bishop JM, Hill DJ, Hopkins CS. Natural history of cow`s milk allergy: clinical outcome. J Pediatr. 1990;116:862-867.

[20] Tikkonen S, Kokkonen J, Juntti H, Niinimaki A. Status of children with cow's milk allergy in infancy by 10 years of age. Acta Paediatr. 2000;89:1174-1180.

[21] Cavataio F, Iacono G, Montalto G, et al. Gastroesophageal reflux associated with cow's milk allergy in infants: which diagnostic examinations are useful? Am $J$ Gastroenterol. 1996;91:1215-1220.

[22] Semeniuk J, Kaczmarski M, Nowowiejska B, Białokoz I, Lebensztejn D. Alergia pokarmowa przyczyną refluksu żołądkowo-przełykowego u dzieci najmłodszych. Pediatr Pol. 2000;110:972-984

[23] Iacono G, Carroccio A, Cavataio F, et al. Gastroesophageal reflux and cow`s milk allergy in infants: a prospective study. J Allergy Clin Immunol. 1996;97:822-827.

[24] Staiano A, Troncone R, Simeone D, et al. Differentiation of cow`s milk intolerance and gastro-oesophageal reflux. Arch Dis Child. 1995:73:439-442.

[25] Hill DJ, Heine RG, Cameron DJS, et al. Role of food protein intolerance in infants with persistent distress attributed to reflux esophagitis. J Pediatr. 2000;136:641-647.

[26] Kokkonen J, Karttunen TJ, Niinimaki A. Lymphonodular hyperplasia as a sign of food allergy in children. $J$ Pediatr Gastroenterol Nutr. 1999;29:57-62.

[27] Kokkonen J, Haapalahti M, Laurila K, et al. Cow's milk protein-sensitive enteropathy At school age. J Pediatr. 2001;139: 797-803.

[28] Kekkonen J, Tikkanen S, Savilahti E. Residual intestinal disease after milk allergy in infancy. $J$ Pediatr Gastroenterol Nutr. 2001;32:156-161.

[29] Iwańczak B, Woźniak Z. Ocena histopatologiczna błony śluzowej przełyku w chorobie refluksowej u dzieci. Pediatr Pol. 2001;76:421-427.

[30] Vieira MC, Pisani JC, Mulinari RA. Diagnosis of reflux esophagitis in infants: histology of the distal esophagus must complement upper gastrointenstinal endoscopy. J Pediatr. 2004;80(3):197-202.

[31] De Angelis P, Markowitz JE, Torroni F, et al: Paediatric eosinophilic oesophagitis: Towards early diagnosis and best treatment. Digestive and Liver Disease. 2006;38:245-251.

[32] Savary M, Miller G. L’ oesophage. Manuel et atlas d`endoscopie. Soleure Gasseman. Paris; 1987.

[33] Ollyo JB, Lang F, Fontolliet C, et al. New endoscpic grading of reflux-oesophagitis: a simple, reproductible, logical, complete and useful classification. Gastroenterology. 1990;98: A100.
[34] Black DD, Haggitt RC, Orenstein SR, et al. Esophagitis in infants. Morphometric Histological Diagnosis and Correlation with Measures of Gastroesophageal reflux. Gastroenterology. 1990;98:1408-1414.

[35] Ismail-Beigi F, Horton P, Pope C. Histologic consequences of gastroesophageal reflux in man. Gastroenterology. 1970;58: 163-174.

[36] Misiewicz JJ, Tytgat GNJ, Goodwin CS, et al. The Sydney System: a new classification of gastritis. Working Party Reports 1990. Med Prakt. 1994;9:89-98.

[37] Maciorkowska E, Kaczmarski M, Kondej-Muszyńska K. Metaplazja w obrębie górnego odcinka przewodu pokarmoweo u dzieci. Gastroenterol Pol. 1998;6:545-551.

[38] Thor P, Herman RM, Frugała A. Refluksowe zapalenie przełyku i jego leczenie. Med Sci Rev (Gastroenterol). 2002;1:120-127.

[39] Salvatore S, Hauser B, Vandenplas Y. The natural course of gastro-oesophageal reflux. Acta Paediatr. 2004;93:607-614.

[40] Ravelli AM, Tobanelli P, Simeone D, et al. Vomiting and gastric motility in infants with cow`s milk allergy. J Pediatr Gastroenterol Nutr. 2001;32:59-64.

[41] Spergel JM. Eosinophilic esophagitis in adults and children: evidence for a food allergy component in many patients. Curr Opin Allergy Clin Immunol. 2007;7:274-278.

[42] Orenstein SR, Shalaby TM, Kesley SF, Frankel E. Natural history of infant reflux esophagitis: symptoms and morphometric histology during one year without pharmacotherapy. Am J Gastroenterol. 2006;101:628-640.

[43] Cherian S, Smith NM, Forbes DA. Rapidly increasing prevalence of eosinophilic oesophagitis in Western Australia. Arch Dis Child. 2006;91:1000-1004.

[44] Winter HS, Madara JL, Stafford RJ, Grand RJ, Quinlan JE, Goldman H. Intraepithelial eosinophils: a new diagnostic criterion for reflux esophagitis. Gastroenterology. 1982;83:818823.

[45] Atwood SE, Smyrk TC, Demeester TR, Jones JB. Esophageal eosinophilia with dysphagia. A distinct clinicopathologic syndrome. Digest Dis Sci. 1993;38:109-116.

[46] Justinisch C, Kalafus D, Esposito P, et al. Mucosal mast cells distinguish allergic from gastroesophageal reflux-induced esophagitis. J Pediatr Gastroenterol Nutr. 1996;23:342 (abstract).

[47] Walsh SV, Antonioli DA, Goldman H, et al. Allergic esophagitis in children: a clinicopathological entity. Am J Surg Pathol. 1999;23:390-396.

[48] Rothenberg ME, Mishra A, Collins MH, Putnam PE. Pathogenesis and clinical features of eosinophilic esophagitis. J Allergy Clin Immunol. 2001;108:891-894.

[49] Jakubczyk M, Czerwionka-Szaflarska M, Zielińska I. Analiza wyników badania endoskopowego górnego odcinka przewodu pokarmowego u dzieci i młodzieży z chorobą refluksową przełyku. Przegl Gastroenterol. 2007;2:42-47.

[50] Tolia V, Ferry G, Gunasekaran T, et al. Efficacy of lansoprazole in the treatment of gastroesophageal reflux disease in children. J Pediatr Gastroenterol Nutr. 2002;35:308-318.

[51] Vakil NB, Shaker R, Johnson DA, et al. The New proton pump inhibitor esomeprazole is effective as a maintenance therapy in GERD patients with healed erosive oesophagitis: a 6-month randomized, double-blind, placebo-controlled study of efficacy and safety. Aliment Pharmacol Ther. 2001;15:927935.

Submitted: 5 February, 2009 Accepted after reviews: 5 April, 2009 